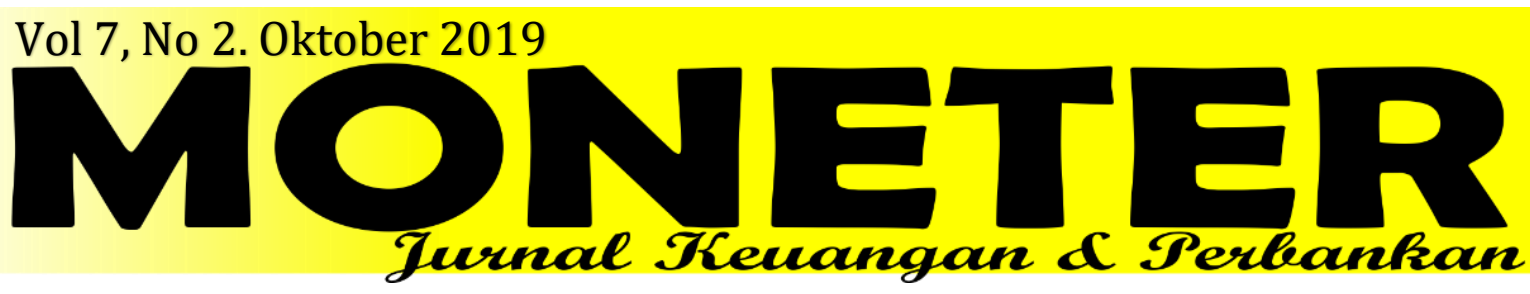

\title{
MEKANISME PENGAWASAN PEMBIAYAAN KONSUMTIF PADA PT. BANK NEGARA INDONESIA SYARIAH (PERSERO) Tbk. KANTOR CABANG PAJAJARAN BOGOR
}

\author{
Rachmatulaily Tina Kartika Rinda dan Nidia Arisandi \\ Program Studi Keuangan dan Perbankan Fakultas Ekonomi dan Bisnis \\ Universitas Ibn Khaldun \\ rachmatulaily@uika-bogor.ac.id
}

\begin{abstract}
Abstrak
Praktek kerja lapangan pada PT Bank BNI Syariah dilakukan dengan mengamati bagaimana mekanisme pengawasan pembiayaan konsumtif, wawancara langsung, verifikasi data, pastikan kebenaran data, dan melihat laporan keuangan. Dari mekanisme tersebut dapat diketahui apakah nasabah mau dan mampu mempertanggung jawabkan pembiayaan yang telah diberikan. Dimana pembiayaan merupakan aktivitas Bank Syariah dalam menyalurkan dana kepada pihak lain atau nasabah. Sebelum dana disalurkan, pihak bank terlebih dahulu menganalisa nasabah apakah layak atau tidak diberikan pembiayaan dengan melakukan pengawasan. Mekanisme pengawasan pembiayaan konsumtif merupakan hal yang sangat penting dalam menyalurkan pembiayaan kepada nasabah. Pengawasan Pembiayaan konsumtif harus menggunakan mekanisme yang benar agar tidak salah dalam mengambil keputusan.
\end{abstract}

Kata kunci : Pengawasan, Pembiayaan, Konsumtif.

\section{Pendahuluan}

\section{Latar Belakang}

Bank adalah lembaga keuangan yang usaha pokoknya memberikan pembiayaan dan jasa di lalu lintas pembayaran dan peredaran uang. Bank sebagai lembaga intermediasi berperan mempercepat pembangunan nasional melalui kegiatan penyaluran pembiayaan. Proporsi penyaluran pembiayaan menentukan perannya dari besar kecilnya pendapatan operasional yang diterima bank. Proporsi penggunaan dana simpanan yang tidak ideal akan mendorong kerugian pada bank tersebut. Oleh karena itu pengelolaan pembiayaan harus di lakukan dengan sebaik-baiknnya dari perencanaan jumlah pembiayaan, pengorganisasiaan, pelaksanaan dan pengawasan pembiayaan yang dilakukan secara kontinyu. Pengelolaan pembiayaan tersebut bertujuan untuk menekan derajat risiko dari aktivitas pembiayaan bank seperti tingginya pembiayaan bermasalah.

Aktivitas pembiayaan bank yang berkualitas dan sehat memberikan pendapatan operasional terbesar bagi bank jika dibandingkan dengan aktivitas lainnya seperti penyediaan layanan. Oleh karena itu untuk meningkatkan pendapatan dan menjaga kelangsungan bank maka pemberian pembiayaan merupakan aktivitas yang secara terus menerus akan dilakukan.

Kegiatan penyaluran pembiayaan disisi lain mengandung risiko yaitu tidak kembalinya dana atau pembiayaan yang disalurkan tersebut karena tidak seluruh nasabah yang memperoleh pembiayaan mampu mengembalikan pembiayaan dengan baik dan 
tepat pada waktunya. Dampak risiko pembiayaan yang diterima bank akan mengganggu tingkat likuiditas bank tersebut. Kebijakan pembiayaan sangat menentukan keberhasilan aktivitas penyaluran pembiayaan dan menekan risiko pembiayaan.

Salah satu upaya untuk lebih mengarahkan agar pembiayaan bank telah didasarkan pada prinsip yang sehat, yaitu melalui pengawasan pembiayaan, baik itu pengawasan sebelum pembiayaan ataupun pengawasan setelah pembiayaan. Pengawasan sebelum pembiayaan ini dilakukan untuk meminimalisir resiko yang akan terjadi selama masa pembiayaan. Sedangkan pelaksanaan pengawasan setelah pembiayaan ini bertujuan untuk menjaga kualitas pembiayaan agar terus berada dalam kategori lancar. Maka dari itu penting bagi BNI Syariah untuk melakukan pengawasan pada pembiayaan nya agar dapat meminimalisir pembiayaan bermasalah yang ada pada bank tersebut.

\section{Rumusan Masalah}

1. Bagaimana Mekanisme pengawasan pembiayaan konsumtif Pada Bank BNI Syariah?

2. Bagaimana Efektifitas pengawasan pembiayaan pada PT BNI Syariah ?

3. Apa Kendala dalam pengawasan pembiayaan PT. Bank BNI Syariah?

\section{Kajian Teori}

\section{Bank}

Pengertian Bank menurut UU RI No.10 th,1998 yang dimaksud dengan Bank adalah badan usaha yang menghimpun dana dari masyarakat dalam bentuk simpanan dan menyalurkannya kepada masyarakat dalam bentuk kredit dan atau bentuk-bentuk lainnya dalam rangka meningkatkan taraf hidup rakyat banyak. (Dr Kasmir,2014:24)

Bank adalah suatu badan usaha yang kegiatan utamanya menerima simpanan dari masyarakat dan atau pihak lainnya, kemudian

\section{Tujuan Penelitian}

1. Untuk mengetahui bagaimana mekanisme pembiyaan konsumtif pada Bank BNI Syariah.

2. Untuk mengetahui bagaimana efektifitas pembiayaan pada Bank BNI Syariah.

3. Untuk mengetahui kendala dalam pengawasan pembiayaan konsumtif pada Bank BNI Syariah.

\section{Manfaat Penelitian}

\section{Bagi Penulis :}

Yaitu sebagai bahan perbandingan bagi penulis antara teori yang di peroleh selama pendidikan dengan penerapan yang di jumpai di dalam perusahaan, dan sebagai bertambahnya ilmu dan wawasan bagi penulis tetang pentingnya pengawasan pembiayaan pada bank.

2. Bagi Akademisi :

Di harapkan hasil penelitian ini dapat menambah referensi, informasi dan wawasan untuk penelitian lebih lanjut atau sebagai bahan kepustakaan serta sumber pengetahuan.

3. Bagi Bank :

Karya ilmiah ini semoga berguna sebagai bahan masukan bagi PT. Bank Negara Indonesia Syariah Bogor dan dapat menjadi bahan pertimbangan dalam pemberian pembiayaan dan pengawasan pembiayaan di masa yang akan datang.

mengalokasikannya kembali untuk memperoleh keuntungan serta menyediakan jasa-jasa dalam lalu lintas pembayaran. (subagio,dkk)

Menurut Dr.B.N.Ajuha bank adalah tempat menyalurkan modal dari mereka yang tidak dapat menggunakan secara menguntungkan kepada mereka yang dapat membuatnya lebih produktif untuk dapat keuntungan masyarakat.

Dari pengertian diatas dapat disimpulkan bahwa bank merupakan perusahaan yang 
bergerak dalam bidang keuangan, artinya aktivitas perbankan selalu berkaitan dengan keuangan. Yang tujuannya yaitu untuk mencari keuntungan dan untuk memperbaiki taraf hidup masyarakat.

\section{Fungsi Bank}

Secara spesifik bank dapat berfungsi sebagai agent of trust, agent of development, dan agent of service (Sigit Triandaru dan Totok Budi Santoso, 2009: 9).

\section{Agent of Trust (kepercayaan)}

2. Agent of Development (tanggung jawab)

3. Agent of Service (pelayanan)

\section{Bank Syariah}

Undang-undang perbankan syariah No.21 tahun 2008 menyatakan bahwa perbankan syariah adalah segala sesuatu yang menyangkut tentang bank syariah dan unit usaha syariah, mencakup kelembagaan, kegiatan usaha, serta cara dan proses dalam melaksanakan kegiatan usahannya.

Bank syariah merupakan bank yang kegiatannya mengacu pada hukum islam, dan dalam kegiatannya tidak membebankan bunga maupun tidak membayar bunga kepada nasabah. Imbalan yang diterima oleh bank syariah maupun yang dibayarkan kepada nasabah tergantung dari akad dan perjanjian antara nasabah dan bank. Perjanjian (akad) yang terdapat di perbankan syariah harus tunduk pada syarat dan rukun akad sebagaimana diatur dalam syariah islam. (Drs. Ismail, MBA., Ak.,2014:32)

\section{Jenis-jenis Bank Syariah}

Jenisnya terdiri atas bank umum syariah (BUS), unit usaha syariah (UUS), dan bank pembiayaan rakyat syariah (BPRS).

1. Bank umum syariah

2. Unit usaha syariah merupakan unit usaha syariah yang masih dibawah pengelolaan bank konvensional.

3. Bank Pembiayaan Rakyat Syariah

\section{Pembiayaan}

Menurut Undang-Undang Perbankan

No. 10 tahun 1998, pembiayaan adalah penyediaan uang atau tagihan yang dapat dipersamakan dengan itu, berdasarkan persetujuan atau kesepakatan antara banj dan pihka lain yang dibiayai untuk mengembalikan uang atau tagihan tersebut setelah jangka waktu tertentu dengan imbalan atau bagi hasil. Di dalam perbankan syariah, pembiayaan yang diberikan kepada pihak pengguna dana berdasarkan pada prinsip syariah. aturan yang digunakan yaitu sesuai dengan hukum islam. (Drs. Ismail,MBA., Ak.2016:105)

Pembiayaan adalah penyediaan dana atau tagihan yang dipersamakan dengan itu berupa: transksi bagi hasil, transaksi sewa menyewa atau sewa beli, transaksi jual beli dalam bentuk piutang, transaksi pinjam meminjam, transaksi sewa menyewa jasa. (Muhamad,2015:40)

\section{Unsur-Unsur Pembiayaan}

1. Bank Syariah

2. Mitra Usaha (Partner)

3. Kepercayaan (Trust)

4. Akad

5. Risiko

6. Jangka Waktu

7. Balas Jasa

\section{Prinsip-Prinsip Pembiayaan}

Untuk dapat melaksanakan kegiatan pembiayaan secara sehat telah dikenal adanya prinsip 5C atau juga ada menyebutkan sebagai prinsip 6C. (Teguh Pudjo Muljono 2001:11)

Kelima prinsip yang klasik ini meliputi:

1. Character (karakter)

2. Capacity (kapasitas)

3. Capital (modal)

4. Collateral (jaminan)

5. Condition of Economy (kondisi ekonomi)

6. Constraint (batasan)

\section{Ruang Lingkup Pengawasan}

Ruang lingkup daripada pengawasan tersebut diatas akan dapat dibedakan lagi secara lebih detail yaitu:

1. Pengawasan dalam arti sempit yaitu berupa pengawasan administratif yang mempunyai 
ruang lingkup untuk mengetahui kebenaran data-data administratif.

2. Pengawasan dalam arti luas yaitu merupakan kegiatan pengendalian didalam suatu perusahaan yang kita kenal dengan manajemen kontrol yang meunyai ruang lingkup yang lebih luas yaitu di bidang:

a. Financial di dalam pelaksanaanya sering kita sebut financial audit;

b. Operational sering kita sebut Operational Audit Performance audit.

c. Management/Policy- sering kita sebut management audit.

\section{Metode Penelitian}

Kegiatan Praktek Kerja Lapangan dilaksanakan dengan dua metode secara langsung dan secara tidak langsung. Metode secara langsung yang telah dilaksanakan selama Praktek Kerja Lapangan meliputi kegiatan yang menyangkut aspek teknis dan

\section{Pembahasan}

Adapun yang menjadi temuan penulis pada saat melakukan praktek kerja lapangan adalah perihal pengawasan pembiayaan, untuk meminimalisir risiko pembiayaan bermasalah, Bank BNI Syariah menggunakan aplikasi eFO (Electronic Financing Origination) sebagai middleware system untuk mendukung layanan bisnis transaksional. Perkembangan eFO yang telah dibangun secara inhouse dilakukan secara terus-menerus untuk memenuhi kebutuhan otomatis pemrosesan pembiayaan yang digunakan secara online. Karena sistem ini online jadi sewaktu-waktu sistem offline atau eror, sehingga harus menunggu beberapa saat untuk sistem kembali normal. Selain itu, perihal pengawasan pembiayaan yang jarak rumah dan usaha nasabah sangat jauh, sehingga untuk pengawasan nya juga maintenance jaminan tidak terpantau. Pengawasan pembiayaan yang jarak rumah dan usaha nasabah sangat jauh, sehingga untuk

\section{Sarana Pengawasan}

Sarana pengawasan dalam pembiayaan adalah sama dengan sarana administrasi pembiayaan namun mempunyai tinjauan yang berbeda-beda. Sarana pengawasan tersebut yang mempunyai tingkat tertinggi tentu dimulai dengan perangkat perundangundangan yang mengatur perbankan dan kegiatan perdagangan pada umumnya dan khususnya yang mengatur bidang pembiayaan. Dan agar ketentuan-ketentuan di atas dapat berjalan dengan baik maka perlu dituangkan dalam bentuk sarana pengawasan yang berupa software dan hardware.

manajerial, serta aspek khusus. Sementara itu metode tidak langsung dilaksanakan selama Praktek Kerja Lapangan adalah mengumpulkan data sekunder dan studi pustaka.

pengawasan nya juga maintenance jaminan tidak terpantau

\section{Kendala yang Dihadapi dan Upaya Untuk Memecahkannya}

Kendala yang dihadapi selama melakukan Praktek Kerja Lapangan di PT. Bank BNI Syariah Cabang Bogor, antara lain:

1. Kendala yang dihadapi:

Sulitnya administrasi pembiayaan (financing support) untuk mencari arsip nasabah karena data nasabah belum di filling data, tidak rapih dan masih berantakan di atas filling cabinet, sehingga menghambat processing untuk melihat data jika dalam keadaan penting.

Upaya memecahkannya:

Jika sudah selesai proses dokumen sebaiknya langsung di susun dengan rapih dan di simpan di filling cabinet sesuai dengan urutan tahun dan nama nasabah. 
2. Kendala yang dihadapi:

Pada saat processing menginput data dari nota penjualan dan pembelian yaitu tidak jelas tulisan nasabah dan angka yang ditulis nasabah pada nota, sehingga menghambat proses kerja processing untuk mengolah data.

Upaya memecahkannya:

Bagian processing harus lebih teliti untuk menginput data dan bisa dilihat dari laporan keuangan yang lainnya selain dari nota pembelian dan nota penjualan.

\section{Kesimpulan}

Berdasarkan yang telah dilakukan, maka penulis menarik kesimpulan sebagai berikut :

1. Mekanisme pengawasan pembiayaan konsumtif yang dilakukan BNI Syariah kantor cabang pajajaran sudah memenuhi kriteria pengawasan pembiayaan dengan tahap permohonan yaitu pengumpulan data untuk diverifikasi lebih lanjut. Tahap proses pembiayaan dilihat kebenaran data, kebenaran usaha dan perhitungan kemampuan biaya serta dilakukan pengecekan lebih dalam tentang nasabah. Tahap putusan sebagai bahan pertimbangan pengambilan keputusan dan wewenang pengambilan keputusan dan tahap pemantauan atau pengawasan setelah realisasi pembiayaan, maka pejabat bank syariah perlu melakukan pemantauan dan pengawasan pembiayaan

2. Efektifitas pengawasan pembiayaan di BNI Syariah sudah melalui beberapa bagian yang meliputi: Bagian operational pengawasan ini terhadap administrasi nasabah. Bagian administrasi pembiayaan pemeriksaaan kelengkapan data nasabah seperti KTP, SIUP, surat perjanjian
3. Kendala yang dihadapi:

Pada saat memfotocopy berkas, mesin fotocopy eror dan tidak bisa digunakan. Sehingga menghambat pekerjaan yang saat itu berkasnya harus dikerjakan .

Upaya memecahkanya:

Mesin fotocopy harus di reset ulang dan dibersihkan bagian dalam yang sudah kotor sehingga tidak terjadi lagi mesin fotocopy mecet saat digunakan.

pembiayaan dan pemeriksaan kepada notaris. Bagian processing meneliti kembali keabsahan data dan jaminan nasabah, memeriksa laporan keuangan, memberikan pembiayaan kepada nasabah dengan jumlah pembiayaan yang disepakati. Bagian collection mengawasi/menjaga nasabah yang jatuh tempo, untuk mencegah nasabah melakukan keterlambatan dalam pembayaran angsuran pembiayaan dan Bagian branch internal control (audit) yaitu mengawasi para pegawai dalam melakukan pekerjaannya, mengawasi dari awal pegawai memberikan pembiayaan sampai pelunasan pembiayaan.

3. Kendala yang dihadapi BNI Syariah dalam pengawasan pembiayaan adalah dokumen nasabah seperti KTP terjadi pemalsuan sehingga proses tidak bisa dilanjutkan atau ditolak dengan memberitahukan calon nasabah lewat surat penolakan. Kurang lengkapnya data nasabah dan persyaratan yang diajukan sehinga menghambat proses pengawasan dan bank harus cepat melakukan rescheduling agar masalah kolektibilitas cepat diselesaikan. 


\section{Daftar Pustaka}

Abdullah, M. Faisal. Dasar-dasar Manajemen Keuangan. Malang: Universitas Muhammadiyah. 2015

Budisantoso, Totok dan Sigit Triandaru. Bank dan Lembaga Keuangan Lain. Jakarta: Salemba Empat. 2006

Ismail. Perbankan Syariah. Jakarta: kencana prenadamedia group. 2018

Kasmir. Bank Dan Lembaga Keuangan Lainnya. Jakarta : Rajawali. 2014

Muhammad. Manajemen Bank Syariah. Yogyakarta : STIM. 2011

Muljono, Teguh, Pudjo. Manajemen Perkreditan. Yogyakarta: BPFE Yogyakarta. 2007
Pradja, Johaya S. Manajemen Perbankan Syariah. Bandung: CV Pustaka Setia. 2015

Raymon Mc.Leod. Jr. Sistem Informasi Manajemen. Jakarta: Prenhallindo. 2004 Subagio, Sri Fatmawati, Rudi Badrudin. Bank lembaga keuangan lainnya. Yogyakarta: STIE YKPN. 2004

Sunaryo. Hukum Lembaga Pembiayaan. Jakarta: Sinar Grafika. 2013

https://www.bnisyariah.co.id/idid/perusahaan/tentangbnisyariah/sejarah 16 Mei 201915.30

https://ahliperbankan.com/job-desc-dantugas-pokok-manajer-cabang-bankbranch-manager/ 1 Juni 201923.50 